\title{
Rate of plasmid transfer among Escherichia coli strains isolated from natural populations
}

\author{
DAVID M. GORDON†
}

Department of Zoology, University of Massachusetts, Amherst, MA 01003, USA

(Received 8 May 1991; revised 16 August 1991; accepted 7 October 1991)

\begin{abstract}
The conjugative plasmid R1 was introduced into ten strains of Escherichia coli isolated from natural populations. Spontaneous nalidixic-acid-resistant mutants of the ten strains served as recipients. The ten donor and recipient strains were mated in all combinations and the rate at which $R 1$ transferred between the strains was determined. The rate of transfer ranged from $5.2 \times 10^{-11}-1.1 \times 10^{-18} \mathrm{ml}$ per cell $\mathrm{h}^{-1}$, and averaged $1.3 \times 10^{-15} \mathrm{ml}$ per cell $h^{-1}$. The results of these experiments suggest that the rates of conjugative transfer are far too low for plasmids to be maintained as parasites in their host populations. Infectious transfer is insufficient; plasmids must confer a selective advantage to their host to be maintained.
\end{abstract}

\section{Introduction}

Plasmids are prevalent symbionts of bacteria. Strains of Escherichia coli, for example, harbour about four plasmids on average (Caugant et al., 1981; Hartl et al., 1986). Traits encoded for by plasmids, such as antibiotic and heavy metal resistance, bacteriocin production, and virulence determinants, may account for a significant portion of their host's adaptation to the environment. However, many plasmids are apparently cryptic, in that no potentially useful characters have been identified. All plasmids propagate themselves vertically and many can propagate horizontally by transferring to new hosts through the processes of conjugation and mobilization. The ability to transfer horizontally allows the possibility that cryptic plasmids may survive in their host populations as parasites, that is, when plasmid carriage represents a cost rather than a benefit to the host.

Stewart \& Levin (1977) addressed the question of whether plasmids can be parasites, by exploring the properties of a mathematical model describing the population dynamics of conjugative plasmids under chemostat culture conditions. Their theoretical analysis demonstrated that parasitic plasmids can invade and establish in a host population provided that,

$$
\gamma N>\alpha \omega+\tau
$$

† Present address: Institute of Parasitology, Macdonald Campus, McGill University, Ste Anne de Bellevue, Quebec H9X 1CO, Canada. where $\gamma$ is the rate of conjugative plasmid transfer, $N$ the equilibrium recipient density, $\alpha$ the selection coefficient, $\tau$ the plasmid segregation rate, and $\omega$ the rate at which plasmids are lost from the population due to washout. Simply stated, the gains to the plasmid population resulting from horizontal transfer must exceed the losses due to selection, segregation, and washout.

Therefore, a knowledge of plasmid transfer rates is critical if any generalizations are to be made concerning the likelihood of plasmids being maintained as parasites in their host populations. Although there have been a few studies that have estimated rates of conjugative transfer (Levin et al., 1979; Freter et al., 1983; Lundquist \& Levin, 1986; Condit \& Levin, 1990; Simonsen, 1990; Simonsen et al., 1990), these studies were concerned with transfer rates between laboratory strains of $E$. coli $\mathrm{K} 12$. Previous studies of conjugative transfer to, or from $E$. coli isolated from natural populations have not determined the rate at which plasmid transfer occurred (Smith, 1969; Burt \& Woods, 1976; Corliss et al., 1981). The purpose of this study was to ascertain the rates of conjugative plasmid transfer among natural isolates of E. coli. The IncFII plasmid Rl was chosen for this study. Earlier in vitro and in vivo studies have determined the conjugative transfer rate of this plasmid, and the transfer rate of $\mathrm{R} 1$ among laboratory E. coli strains appears to be representative of the transfer rate of plasmids from other incompatibility groups which encode for antibiotic resistance (Lundquist \& Levin, 1986; Condit \& Levin, 1990). 


\section{Methods}

Bacteria and plasmids. The source of the wild-type strains was the ECOR collection, a set of $72 \mathrm{E}$. coli clones isolated from man, domestic and zoo animals (Ochman \& Selander, 1984). The E. coli K12 strain $\mathrm{CSH} 50$ [ $\Delta($ lac-pro) ara rps $L$ gyr $A]$ was used as a plasmid recipient in some mating experiments. The IncFII plasmids used were $\mathrm{R} 1(\mathrm{Cm} \mathrm{Km}$ $\mathrm{Ap} \mathrm{Sm} \mathrm{Su}$ ) and $\mathrm{R} 1 d r d 19$ maintained in the E. coli K12 strain J53 (met pro). $\mathrm{R} 1$ is normally repressed for conjugative pilus synthesis, while $\mathrm{R} 1$ drd 19 is a permanently derepressed mutant of $\mathrm{R} 1$.

Strain construction. The auxotrophic R1 plasmid donor J53 was mated with members of the ECOR collecton which are all prototrophs. The matings were done in Luria broth at $37^{\circ} \mathrm{C}$. Cells of the ECOR strain that had acquired the plasmid were selected by plating on minimal salts medium containing glucose $\left(10 \mathrm{~g} \mathrm{t}^{-1}\right)$ and chloramphenicol $\left(25 \mathrm{mg} \mathrm{l}^{-1}\right)$. This was done for all of the odd-numbered strains in the ECOR collection. A substantial number of the ECOR strains are colicinogenic or infected with temperate bacteriophage (unpublished data). The mortality caused by colicins or temperate bacteriophage during a mating experiment could result in an inaccurate estimate of the transfer rate. To avoid this, the colicinogenic strains and those harbouring temperate bacteriophage were discarded and the ten strains used in the transfer rate experiments were chosen from among those remaining.

Spontaneous nalidixic-acid-resistant mutants of the ten original ECOR strains were used as plasmid recipients. The plasmid R1drd 19 was transferred to the ten ECOR strains using the procedure described for Rl. Native plasmid profiles were obtained using agarose gel electrophoresis (Sambrook et al., 1989). Hartl et al. (1986) found that, in $E$. coli, most plasmids are either less than $8 \mathrm{~kb}$ (small) or more than $40 \mathrm{~kb}$ (large) in size. The plasmid profiles of the ten ECOR strains showed a similar pattern, and the strains were scored for the presence or absence of large and small plasmids (excluding R1). The ECOR strains selected and their relevant characteristcs are presented in Table 1 .

Transfer rate experiments. Each of the ECOR donor strains was mated with the ten ECOR recipient strains. Each mating combination was relicated five times. Matings were done in $50 \mathrm{ml}$ Erlenmeyer flasks containing $10 \mathrm{ml}$ Luria broth. The flasks were inoculated with cells from overnight broth cultures to produce an initial density of about $3 \times 10^{7}$ cells $\mathrm{ml}^{-1}$ and a $1: 1$ donor : recipient ratio. The cultures were incubated at $37^{\circ} \mathrm{C}$ and shaken at 150 r.p.m. Stationary-phase cell densities were estimated by serial dilution and selective plating on TL plates: Luria broth with 2,3,5-triphenyltetrazolium chloride $\left(50 \mathrm{mg}^{-1}\right)$ and lactose $\left(10 \mathrm{~g} \mathrm{l}^{-1}\right)$. Donors were selected with chloramphenicol $\left(25 \mathrm{mg} \mathrm{l}^{-1}\right)$, recipients with nalidixic acid $\left(20 \mathrm{mg} \mathrm{l}^{-1}\right)$ and transconjugants with chloramphenicol and nalidixic acid.

Estimating plasmid transfer rate. The rate of conjugative plasmid transfer, $\gamma\left(\mathrm{ml}\right.$ per cell $\left.\mathrm{h}^{-1}\right)$, was determined using the end point method of Simonsen et al. (1990):

$$
\gamma=\psi \ln \left(1+\frac{T}{R} \cdot \frac{N}{D}\right) \cdot \frac{1}{N}
$$

where $T, D$, and $R$ are the transconjugant, donor and recipient densities (cells $\mathrm{ml}^{-1}$ ) at sampling, respectively, $N=T+D+R$ and $\psi\left(\mathrm{h}^{-1}\right)$ is the exponential phase population growth rate. This method of determining plasmid transfer rates produces reliable estimates under a wide range of experimental conditions, and is independent of initial or final cell densities and donor:recipient ratios (Simonsen et al., 1990). The exponential phase growth rate of each donor and recipient strain was measured individually. Growth rates in Luria broth at $37^{\circ} \mathrm{C}$ and 150 r.p.m. were measured by $\mathrm{OD}_{675}$. The growth rate estimates were based on the average of three replicates. Growth rates of the ECOR donor and recipient strains ranged from $1 \cdot 7-2 \cdot 0 \mathrm{~h}^{-1}$ (Table 1). The growth rate of the $E$. coli $\mathrm{K} 12$ strain $\mathrm{CSH} 50$ was $1.9 \mathrm{~h}^{-1}$. To arrive at an estimate of the transfer rate, $\psi$ was assumed to be the average of the individual growth rates of the two strains involved in a mating.

Substantial differences in the growth rates of the donor and recipient strains, or significant rates of plasmid segregation will result in inaccurate estimates of the rate of transfer (Simonsen et al., 1990). The greatest growth rate difference for any donor recipient strain combination was $15 \%$ (Table 1). Differences of this magnitude will result in roughly a $5 \%$ error in the transfer rate estimate (Simonsen $e t$ al., 1990). Rl segregation frequencies were estimated in the following manner for each ECOR donor. Cells from an overnight Luria broth culture were diluted and plated on TL medium. Colonies $(n=1500)$ from the TL plates were toothpicked on to TL plates containing ampicillin (200 $\left.\mathrm{mg} \mathrm{l}^{-1}\right)$, kanamycin $\left(50 \mathrm{mg} \mathrm{l}^{-1}\right)$ and chloramphenicol $\left(25 \mathrm{mg} \mathrm{l}^{-1}\right)$. Equating loss of the three markers with loss of the plasmid resulted in segregation frequencies ranging from $0-2 \times 10^{-4}$. The segregation rates suggested by these frequencies are sufficiently small that segregation will have an undetectable effect on the transfer rate estimate (Simonsen et al., 1990).

\section{Results}

\section{RI plasmid transfer rates among the ECOR strains}

The estimated rate of $\mathrm{R} 1$ transfer between $E$. coli isolated from natural populations ranged from $5.2 \times 10^{-11}$ $1 \cdot 1 \times 10^{-18} \mathrm{ml}$ per cell $\mathrm{h}^{-1}$; overall, the average rate of $\mathrm{R} 1$ transfer was $1.3 \times 10^{-15} \mathrm{ml} \mathrm{cell} \mathrm{h}^{-1}$ (Table 2). Donor and recipient effects accounted for a similar amount of the total variation observed in the transfer rates, 29 and $25 \%$ respectively; donor-recipient interaction effects accounted for $41 \%$ of the variation (Table 3). No association was observed between the average donor ability of a strain and its average ability as a recipient. For example, the strain ECOR 1 was the best recipient overall, but was one of the poorest donors (Table 2).

Table 1. Characteristics of the E. coli strains used in this study

\begin{tabular}{|c|c|c|c|c|c|}
\hline \multirow[b]{2}{*}{ Strain* } & \multirow[b]{2}{*}{ Source } & \multicolumn{2}{|c|}{$\begin{array}{l}\text { Native plasmid } \\
\text { burden } \dagger\end{array}$} & \multicolumn{2}{|c|}{ Growth rate $\left(h^{-1}\right) \ddagger$} \\
\hline & & Large & Small & Rl donor & Recipient \\
\hline 1 & Human & - & + & 1.87 & 1.97 \\
\hline 5 & Human & - & + & 1.72 & 1.77 \\
\hline 27 & Giraffe & + & + & 1.72 & 1.72 \\
\hline 33 & Sheep & - & - & 1.75 & 1.76 \\
\hline 35 & Human & + & + & 1.73 & 1.74 \\
\hline 45 & Pig & - & - & 1.76 & 1.86 \\
\hline 47 & Sheep & + & - & 1.82 & 1.74 \\
\hline 55 & Human & + & + & 1.72 & $1 \cdot 70$ \\
\hline 57 & Gorilla & - & + & 1.89 & 1.84 \\
\hline 69 & Ape & - & + & $2 \cdot 01$ & $2 \cdot 01$ \\
\hline
\end{tabular}

* The strains are a subset of the ECOR collection, a set of strains isolated from natural populations.

† Native plasmids scored with respect to presence $(+)$ or absence $(-)$ of large $(>40 \mathrm{~kb})$ or small $(<8 \mathrm{~kb})$ plasmids.

$\ddagger$ Mean growth rate $(n=3)$ estimated in Luria broth at $37^{\circ} \mathrm{C}$ from $\mathrm{OD}_{675}$ measurements. 
Table 2. Mean transfer rates $(\log \gamma ; n=5)$ of plasmid $R I$ among $E$. coli isolated from natural sources

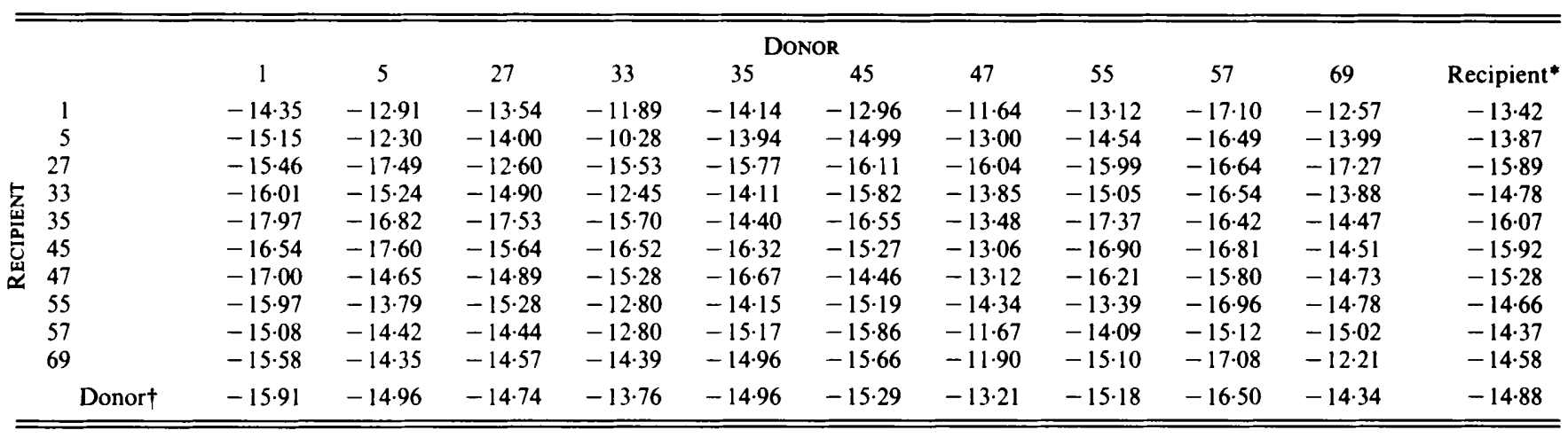

* Row average. $†$ Column average.

Table 3. Analysis of variance for the RI mating matrix (Table 2)

DF, Degrees of Freedom; SS, sums of squares; MS, mean squares; F, F statistic.

\begin{tabular}{lrrrrcrc}
\hline \hline Source & DF & \multicolumn{1}{c}{ SS } & MS & F & $P$ & $\begin{array}{c}\text { Total } \\
\text { variance* } \\
(\%)\end{array}$ \\
\hline Donor & 9 & 414.36 & 46.04 & 7.96 & $<0.001$ & 29.3 \\
Recipient & 9 & 362.19 & 40.24 & 6.96 & $<0.001$ & 25.1 \\
Interaction & 81 & 468.43 & 5.78 & 47.42 & $<0.001$ & 41.2 \\
Error & 400 & 48.79 & 0.12 & & & 4.4 \\
Total & 499 & 1290.36 & & & & \\
\hline \hline
\end{tabular}

* Calculated assuming donors and recipients are a random sample of all possible E. coli strains (Sokal \& Rohlf, 1981; p. 337).

Table 4. The effect of native plasmid burden on the transfer rate of $R I$ among natural isolates of $E$. coli

\begin{tabular}{|c|c|c|c|c|c|}
\hline & \multicolumn{2}{|c|}{$\begin{array}{l}\text { Native plasmid } \\
\text { burden }\end{array}$} & \multicolumn{2}{|c|}{ Rank of transfer rate } & \multirow[b]{2}{*}{$\chi^{2}$ test } \\
\hline & Large & Small & $>$ Median & $<$ Median & \\
\hline \multirow[t]{4}{*}{ Donors } & - & - & 8 & 12 & NS \\
\hline & - & + & 18 & 22 & NS \\
\hline & + & - & 6 & 4 & NS \\
\hline & + & + & 18 & 12 & NS \\
\hline \multirow[t]{4}{*}{ Recipients } & - & - & 5 & 15 & $\dagger$ \\
\hline & - & + & 33 & 7 & $\dagger$ \\
\hline & + & - & 1 & 9 & $\dagger$ \\
\hline & + & + & 11 & 19 & NS \\
\hline
\end{tabular}

- NS, $P>0.05 ; \dagger, P<0.05$.

\section{Effect of genetic distance between donor and recipient}

Higher rates of $\mathrm{Rl}$ transfer were observed when the donor strain was mated to self. On average, the rate of transfer was ten times faster in matings with self than matings with non-self. In six out of ten cases, the highest rate of transfer was obtained in the mating with self (diagonal, Table 2) as compared to matings with the other recipients (columns, Table 2).

The ECOR collection has been used in a number of studies of genetic variation in $E$. coli populations. Genetic distances between the ten strains were estimated from published dendrograms constructed using protein electrophoresis, and biotype data (Miller \& Hartl, 1986; Selander et al., 1987; T. Whittam, personal communication). Beyond the effect of matings with self (zero genetic distance), no relationship was detected between the rate of Rl transfer and the degree to which the strains were related.

\section{Effect of native plasmid burden}

Eight of the ten ECOR strains carried plasmids (Table 1). Native plasmid gels of the original ECOR strains and ECOR Rl donors showed that no native plasmids were lost as a result of transferring $R l$ to these strains. When the hosts were scored for the presence or absence of large or small plasmids, there were four classes of native plasmid carriage (Table 1). The 100 donor-recipient strain combinations were ranked by their average rate of R1 transfer. The effect of native plasmid burden on $R 1$ donor ability was assessed by scoring the number of times a plasmid carriage class was associated with a transfer rate greater than the median transfer rate. The effect of plasmid carriage on recipient ability was scored in the same manner. The results of this analysis are presented in Table 4.

No effect of native plasmid burden on donor ability could be detected. Native plasmid burden did influence recipient ability. Transfer rates greater than the median transfer rate were more likely when recipients had small, but no large plasmids. Transfer rates to recipients with only large plasmids were lower than expected, as were the rates to recipients with no plasmids. 
Table 5. Mean transfer rate $(\log \gamma ; n=5)$ of $R 1$ and $R 1 d r d 19$ in matings involving natural isolates of $E$. coli and E. coli $K 12$ strains

\begin{tabular}{ccccr}
\hline \hline ECOR strain & $\begin{array}{l}\text { Donor } \\
\text { Plasmid } \\
\text { Recipient }\end{array}$ & $\begin{array}{c}\text { J53 } \\
\text { R1 } \\
\text { ECOR }\end{array}$ & $\begin{array}{c}\text { ECOR } \\
\text { R1 } \\
\text { CSH50 }\end{array}$ & $\begin{array}{c}\text { ECOR } \\
\text { R1drd19 } \\
\text { CSH50 }\end{array}$ \\
\hline 1 & & -13.19 & -13.25 & -9.52 \\
5 & -13.79 & -12.09 & -8.88 \\
27 & -16.43 & -11.50 & -11.23 \\
33 & -13.97 & -11.65 & -8.69 \\
35 & -16.09 & -12.47 & -10.83 \\
45 & -16.33 & -11.40 & -10.91 \\
47 & -14.65 & -10.25 & -10.55 \\
55 & -13.28 & -12.23 & -9.06 \\
57 & -11.57 & -13.84 & -12.38 \\
69 & -13.92 & -12.07 & -8.98 \\
Average & -14.32 & -12.08 & -10.10 \\
\hline \hline
\end{tabular}

\section{Transfer rates between laboratory and wild-type strains}

In matings where the $E$. coli $\mathrm{K} 12$ strain $\mathrm{J} 53$ served as the $\mathrm{R} 1$ donor and the ECOR strains as the recipients, the average transfer rate was only slightly greater than when the ECOR strains served as both donors and recipients (Table 5). When the ECOR strains served as donors and the $E$. coli $\mathrm{K} 12$ strain $\mathrm{CSH} 50$ as the recipient, $\mathrm{R} 1$ transferred, on average, 100 times faster than when the ECOR strains served as recipients (Table 5). In matings using the ECOR strains as the donor of R1drd 19, and CSH50 as its recipient, the average transfer rate obtained was $7.9 \times 10^{-11} \mathrm{ml}$ per cell $\mathrm{h}^{-1}$ (Table 5).

\section{Discussion}

Overall the rate of $\mathrm{R} 1$ transfer was more than 1000 times slower than the $2.7 \times 10^{-12} \mathrm{ml}$ per cell h-1 rate obtained in matings involving $E$. coli $\mathrm{K} 12$ donors and recipients (Simonsen et al., 1990). Although there are substantial differences in donor ability among the ECOR strains (Tables 2 and 5), much of the observed variation in $\gamma$ appears to be due to recipient effects. When the ECOR strains served as $\mathrm{R} 1$ donors and CSH50 as the recipient the average rate of $R 1$ transfer was $9.4 \times 10^{-13} \mathrm{ml}$ per cell $\mathrm{h}^{-1}$ (Table 5), a rate not much lower than the rate obtained using $E$. coli $\mathrm{K} 12$ donor and recipients. However, when the ECOR strains served as recipients and $\mathrm{J} 53$ as the donor, the average rate of transfer was $4.8 \times 10^{-15} \mathrm{mi}$ per cell $\mathrm{h}^{-1}$ (Table 5), substantially lower than that obtained in matings between $E$. coli $\mathrm{K} 12$ strains.

Two factors contributing to the variation in recipient ability can be identified from the data. The first relates to the genetic relatedness of donor and recipient, as matings with self gave higher transfer rates than matings with non-self (Table 2). The second factor concerns the native plasmid burden of the recipient (Table 4). Freter et al. (1983) observed that the transfer rate of R1drd19 between $E$. coli $\mathrm{K} 12$ strains was enhanced if the recipient harboured the small plasmid pBR322. However, he also reported that the presence of pBR322 in the R1drd 19 donor decreased the rate of $\mathrm{R} 1 d r d 19$ transfer to a plasmid-free recipient, a result not observed in this study.

Unlike R1, many wild-type plasmids are not normally repressed for conjugative pilus synthesis and transfer at a much faster rate than $\mathrm{R} 1$. In matings between $E$. coli $\mathrm{K} 12$ strains, the derepressed plasmid R1drd 19 transfers at a rate of about $5 \times 10^{-8} \mathrm{ml}$ per cell $\mathrm{h}^{-1}$ (Levin et al. 1979). When the ECOR strains served as R1drd 19 donors and CSH50 as the recipient, $\gamma$ averaged $7.9 \times 10^{-11} \mathrm{ml}$ per cell $\mathrm{h}^{-1}$ (Table 5). Freter et al. (1983) reported a transfer rate of about $4 \times 10^{-16} \mathrm{ml}$ per cell h-1 in matings where an $E$. coli $\mathrm{K} 12$ strain served as the R1drd 19 donor and a natural $E$. coli isolate as the recipient. These results suggest that, in matings between wild-type $E$. coli, the transfer rate of non-repressed plasmids will be several orders of magnitude lower than observed for R1drd 19 in matings using $E$. coli $\mathrm{K} 12$ strains.

R1 transfer rates were obtained from matings carried out in well aerated Luria broth cultures at $37^{\circ} \mathrm{C}$. How representative are these rates with respect to the rates that might be obtained in bacterial populations in natural environments? Transfer rates estimated from batch mating cultures using richer media, such as Terrific broth (Sambrook et al., 1989) are not greater than those obtained in Luria broth (unpublished data). The transfer rates obtained using glucose minimal salts media are slightly lower than for Luria broth (Simonsen et al., 1990). The rate of $\mathrm{R} 1$ transfer is temperaturedependent and the maximum rate of $R 1$ transfer is obtained at $37^{\circ} \mathrm{C}$ (Simonsen et al., 1990). Freter et al. (1983) determined the transfer rates of R1 and R1drd 19 between $E$. coli $\mathrm{K} 12$ strains under anaerobic conditions, in vitro using chemostat cultures, and in vivo using gnotobiotic mice, in the presence or absence of the normal indigenous microflora of the mouse large intestine. The transfer rates they estimated for these plasmids were never greater, and were of ten lower, than the rates obtained in well-aerated Luria broth batch culture matings. These results strongly suggest that the plasmid transfer rates estimated in this study are the maximum that can be expected, and that any deviation from these conditions will result in lower rates of transfer.

Can plasmids be maintained as parasites in their host populations by infectious transfer alone, without conferring a selective advantage to their hosts? Levin (1980) 
has shown that given typical bacterial densities in natural populations $\left(10^{8}-10^{7}\right.$ cells $\left.\mathrm{ml}^{-1}\right)$, costs of plasmid carriage $(0 \cdot 0-0 \cdot 15)$, segregation $\left(10^{-3} \mathrm{~h}^{-1}\right)$ and dilution rates $\left(0.02-0 \cdot 2 \mathrm{~h}^{-1}\right)$, the rate of plasmid transfer would have to be greater than $1 \times 10^{-10} \mathrm{ml}$ per cell $\mathrm{h}^{-1}$ for a plasmid to be maintained by infectious transfer. In none of the 100 mating combinations was an $\mathrm{R} 1$ transfer rate of this magnitude obtained, suggesting that repressed conjugative plasmids cannot be maintained as parasites. The $\mathrm{R} 1 d r d 19$ results suggest that, at best, a very small fraction of non-repressed conjugative plasmids would exhibit the necessary transfer rate. Some plasmids can transfer to new hosts through the process of mobilization. Levin \& Stewart (1980) have shown that the invasion and establishment conditions for non-conjugative but mobilizable plasmids are more restricted than those for conjugative plasmids. Thus the conclusion suggested by these results is that it is very unlikely that plasmids can be maintained, as parasites, by infectious transfer.

I wish to thank Lone Simonsen and Bruce Levin for many useful discussions and suggestions. The research was supported by the Environmental Protection Agency, the Medical Research Council of Canada and a National Institute of Health grant, GM33782.

\section{References}

BURT, S. J. \& Woods, D. R. (1976). R factor transfer to obligate anaerobes from Escherichia coli. Journal of General Microbiology 93, 405-409.

Caugant, D. A., Levin, B. R. \& Selander, R. K. (1981). Genetic diversity and temporal variation in the $E$. coli population of a human host. Genetics $98,467-490$.

Condit, R. \& Levin, B. R. (1990). The evolution of plasmids carrying multiple antibiotic resistance genes: the role of segregation, transposition, and homologous recombination. American Naturalist 135, 573-596.
Corliss, T. L., Cohen, P. S. \& Cabelli, V. J. (1981). R-plasmid transfer to and from Escherichia coli strains isolated from human fecal samples. Applied and Environmental Microbiology 41, 959-966.

FreTER, R., FreTER, R. R. \& BRICKNER, H. (1983). Experimental and mathematical models of Escherichia coli plasmid transfer in vitro and in vivo. Infection and Immunity 39, 60-84.

Hartl, D. L., Medhora, M., Green, L. \& Dykhuizen, D. E. (1986). The evolution of DNA sequences in Escherichia coli. Philosophical Transactions of the Royal Society, Serial B 312, 191-204.

LEVIN, B. R. (1980). Conditions for the existence of R-plasmids in bacterial populations. In Antibiotic Resistance: Transposition and Other Mechanisms. Edited by S. Mitsuhashi, L. Rosival, \& V. Krcmery. Berlin: Springer Verlag.

LeVIN, B. R. \& StewART, F. M. (1980). The population biology of bacterial plasmids: a priori conditions for the existence of mobilizable nonconjugative factors. Genetics $94,425-443$.

Levin, B. R., Stewart, F. M. \& Rice, V. A. (1979). The kinetics of conjugative plasmid transmission: fit of a simple mass action model. Plasmid 2, 247-260.

LuNDQUisT, P. D. \& LEVIN, B. R. (1986). Transitory derepression and the maintenance of conjugative plasmids. Genetics 113, 483-497.

MILlER, R. D. \& HARTL, D. L. (1986). Biotyping confirms a nearly clonal population structure in Escherichia coli. Evolution 40, 1-12.

OChman, H. \& Selander, R. K. (1984). Standard reference strains of Escherichia coli from natural populations. Journal of Bacteriology 157 , 690-693.

Sambrook, J., Fritsch, E. F. \& Maniatis, T. (1989). Molecular Cloning: A Laboratory Manual, 2nd edn. Cold Spring Harbor, NY: Cold Spring Harbor Laboratory.

Selander, R. K., Caugant, D. A. \& Whittam, T. S. (1987). Genetic structure and variation in natural populations of Escherichia coli. In Escherichia coli and Salmonella typhimurium: Cellular and Molecular Biology. Edited by F. C. Neidhardt. Washington: American Society for Microbiology.

SimONSEN, L. (1990). Dynamics of plasmid transfer on surfaces. Journal of General Mcirobiology 136, 1001-1007.

Simonsen, L., Gordon, D. M., StewarT, F. M. \& Levin, B. R. (1990) Estimating the rate of plasmid transfer: an end-point method. Journal of General Microbiology 136, 2319-2325.

SMITH, H. W. (1969). Transfer of antibiotic resistance from animal and human strains of Escherichia coli to resident $E$. coli in the alimentary tract of man. Lancet 1, 1174-1176.

SoKal, R. R. \& RoHLF, F. J. (1981). Biometry, 2nd edn. San Francisco: W. H. Freeman.

StewART, F. M. \& Levin, B. R. (1977). The population biology of bacterial plasmids: a priori conditions for the existence of conjugationally transmitted factors. Genetics 87, 209-228. 